\title{
1021- Asthma diagnosis and treatment - 1021. Prevalance of wheezing and risk factor of asthma in preschool children, South Korea
}

Sung-\|l Woo

From 2nd WAO International Scientific Conference (WISC 2012)

Hyderabad, India. 6-9 December 2012

\section{Background}

Childhood asthma is frequently perceived as a disease with uniform clinical pathways. This perception might be an oversimplification. The aim of the present study was to investigate the prevalence of wheeze in children $\leq 6$ yrs of age and the proportios of children with the risk factors predicting asthma at school children.

\section{Methods}

The Green Breath for Children( GBC) recruited 1,354 preschool children who live in Jincheon area and are $\geq 2$ yrs of age in 2011. Physical examinations, questionare for allergic and respiratory disease and skin prick tests were performed.

\section{Results}

Among 1534 preschool children, 1219 (90.0\%) has completed response to questionare. Complete data were available for 1169 children about past medical history including wheeze, familial history and skin prick test. The prevalence of wheeze was $29.4 \%$.It was found that incidence of wheezing declined and incidence of aeroallergen sensitization increased with age. Two hundred and ten preschool children had wheeze at $\geq 3$ yrs of age. Two hundred and seventy three (22.3\%) has associated risk factor of progression toward atopic asthma.

\section{Conclusions}

There were high prelevance of wheeze and presence of risk factor of atopic asthma. So it is needed that other methods or markers are able to discriminate children who

Department of Pediatrics, Chungbuk National University Hispital, Cheongju, South Korea will have progresssion to asthma and asthma exacerbation in school childhood among wheezer in preschool children.

Published: 23 April 2013

doi:10.1186/1939-4551-6-S1-P20

Cite this article as: Woo: 1021- Asthma diagnosis and treatment 1021. Prevalance of wheezing and risk factor of asthma in preschool children, South Korea. World Allergy Organization Journal 2013 6(Suppl 1): P20.
Submit your next manuscript to BioMed Central and take full advantage of:

- Convenient online submission

- Thorough peer review

- No space constraints or color figure charges

- Immediate publication on acceptance

- Inclusion in PubMed, CAS, Scopus and Google Scholar

- Research which is freely available for redistribution
C Biomed Central 